\title{
AT-TARBAWI
}

At-Tarbawi: Jurnal Pendidikan, Sosial dan Kebudayaan

Volume 6 Nomor 1 Tahun 2019

doi: 10.32505/tarbawi.v6i1.1029

\section{Integrasi Al-Quran pada Mata Pelajaran Matematika terhadap Kemampuan Siswa}

\author{
Fenny Anggreni \\ IAIN Langsa \\ Email: fenny@iainlangsa.ac.id
}

\begin{abstract}
The purpose of Education in Indonesia is to develop students' abilities in various aspects, both in the areas of cognitive ability and religious ability. One of the efforts to fulfil that goal is by integrating general science with religious knowledge. An example of this Integration is to associate mathematics with the Quran. The reason behind this integration is that the contents of the Qur'an cover many of the symbols of numbers and meanings that are also part of mathematics. This integration is also applied to educational institutions in Indonesia. It's just a bit of research done to integrate mathematics education with the Quran to improve students' ability in Indonesia as well as in Aceh, especially Aceh Tamiang who have never done the research. Related to existing literature gaps so this study was conducted to analyze how the integration of the Qur'an on mathematics subjects on students' ability in MTs Aceh Tamiang. This type of research uses quantitative research with an experimental approach, its design research uses a One-shot case study design, the instrument uses a test. The results show that the application of the Qur'an in mathematics subjects at MTs Aceh Tamiang is said to be good because students are above average. It is therefore advisable for other schools to apply the Qur'an in mathematics subjects.
\end{abstract}

Keywords: Ability, Mathematics, Quran, Student

\begin{abstract}
Abstrak
Tujuan Pendidikan di Indonesia adalah untuk mengembangkan kemampuan siswa dalam berbagai aspek, baik dalam bidang kemampuan kognitif maupun kemampuan keagamaan. Salah satu upaya untuk dapat memenuhi tujuan tersebut adalah dengan cara mengintegrasikan ilmu pengetahuan umum dengan ilmu pengetahuan agama. Contoh Integrasi ini adalah dengan mengaitkan mata pelajaran matematika dengan Al-Quran. Alasan dibalik integrasi ini dikarenakan kandungan Al-Quran banyak mencakup tentang simbolsimbol angka dan makna yang juga merupakan bagian dari matematika. Integrasi ini juga diterapkan di Institusi pendidikan di Indonesia. Hanya saja masih sedikit penelitian yang dilakukan untuk mengintegrasi pendidikan matematika dengan Al-Quran untuk meningkatkan kemampuan siswa di Indonesia demikian juga di Aceh terutama Aceh Tamiang yang belum pernah melakukan penelitian tersebut. Terkait dengan kesenjangan literatur yang ada sehingga penelitian ini dilakukan untuk menganalisa bagaimana integrasi Al-Quran pada mata pelajaran matematika terhadap kemampuan siswa di MTs Aceh Tamiang. Jenis penelitian ini menggunakan penelitian kuantitatif dengan pendekatan eksperimen, desain penelitiannya menggunakan One shot case study design, instrumennya menggunakan tes. Hasil penelitian menunjukkan bahwa penerapan Al-Quran pada mata pelajaran matematika di MTs Aceh Tamiang dikatakan baik karena siswa berada di atas rata-rata. Maka disarankan untuk sekolah-sekolah lain untuk menerapkan Al-Quran pada mata pelajaran matematika.
\end{abstract}

Kata kunci: Al-Quran, Kemampuan, Matematika, Siswa 


\section{A. Pendahuluan}

Perkembangan dalam pendidikan matematika beserta tuntutannya tidak dapat dipisahkan dari kehidupan sehari-hari. Hal ini dapat dipahami, karena tujuan pendidikan antara lain adalah untuk mempersiapkan manusia yang mampu hidup layak ditengah masyarakat. Pendidikan dasar dan menengah bertujuan untuk mempersiapkan siswa agar sanggup menghadapi perubahan keadaan dalam kehidupan sehari-hari dan dunia yang selalu berkembang, melalui latihan bertindak atas dasar pemikiran logis, rasional, kritis, cermat, jujur, efektif dan efisien.

Matematika merupakan ilmu yang sentral dalam kehidupan seharihari dan matematika sudah dikenalkan sejak dini. Begitu banyak kegiatan kita yang telah menggunakan matematika dalam kehidupan sehari-hari. Matematika memiliki pengaruh yang besar dalam kehidupan manusia seseorang tidak dapat terlepas dari matematika. Tetapi bagi sebagian besar orang menganggap bahwa matematika merupakan ilmu yang amat berat dan sulit. Salah satu hal yang perlu dilakukan untuk mengintegrasikan matematika dengan Islam yaitu terlebih dahulu mengetahui apa itu matematika dan bagaimana sifatnya. Istilah matematika berasal dari kata Yunani, mathein atau manthenein yang berarti mempelajari. Kata ini memiliki hubungan yang erat dengan kata Sansekerta, medha atau widya yang memiliki arti kepandaian, ketahuan, atau intelegensia (Erman, Suherman, 2003).

Sifat atau karakteristik dari matematika terdiri dari objek matematika abstrak, memiliki simbol yang kosong dari arti, bertumpu pada kesepakatan, berpola pikir deduktif, konsisten dalam sistemnya, dan memperhatikan semesta pembicaraannya. Keberadaan simbol ini memberi peluang yang besar kepada matematika untuk digunakan dalam berbagai ilmu dan kehidupan nyata. Seperti contoh simbol 1, 2, 3, 4, dan seterusnya tidak memiliki makna apa-apa, akan tetapi ide bilangan 1, 2, 3, dan seterusnya ada di alam, ide seperti banyaknya benda yang dimiliki oleh seseorang berjumlah 2 dan sebagainya. 
Mempelajari ilmu pengetahuan alam adalah bagian dari mempelajari agama sebab agama telah memerintahkannya. Ajaran Islam memerintahkan terhadap umatnya untuk menelaah alam semesta dalam rangka mendekatkan diri kepada Allah SWT demi tercapainya kebahagiaan di dunia dan akhirat. Begitu juga dengan matematika, seperti yang dikemukakan oleh Abdusysyakir (2006) dalam bukunya yang berjudul Ketika Kyai Mengajar Matematika, sesungguhnya matematika itu memiliki hubungan yang sangat erat dengan tradisi spiritual umat Islam, akrab dengan al-Qur'an, dan tentunya matematika juga dapat dijadikan sebagai "jalan" menuju pencapaian manfaat-kebahagiaan baik di dunia maupun akhirat. Berangkat dari permasalahan di atas, penulis tertarik untuk meneliti mengenai bagaimana Integrasi Al-Quran pada Mata Pelajaran Matematika Terhadap kemampuan Siswa di MTs Aceh Tamiang.

Matematika adalah kegiatan belajar yang berkaitan tentang bilangan, hubungan antara bilangan dan prosedur operasional yang digunakan dalam penyelesaian masalah mengenai bilangan pada peserta didik. Pola tingkah laku manusia yang tersusun menjadi suatu model sebagai prinsip-prinsip belajar diaplikasikan ke dalam matematika. Prinsip belajar ini haruslah dipilih sehingga cocok untuk mempelajari matematika. Matematika yang berkenaan dengan ide-ide abstrak yang diberi simbol-simbol itu tersusun secara hirarkis dan penalarannya deduktif, sehingga jelaslah belajar matematika merupakan kegiatan mental tinggi (Herman Hudojo, 1988: 3). Secara umum definisi matematika dapat dideskripsikan sebagai berikut (Abdul Halim Fathani: 23):

1. Matematika sebagai strukturyang terorganisasi

2. Matematika sebagai alat (tool)

3. Matematika sebagai pola pikir deduktif

4. Matematika sebagai cara bernalar (the way of thinking)

5. Matematika sebagai bahasa artifisia

6. Matematika sebagai seni yang kreatif 
Dari berbagai definisi di atas ada beberapa ciri matematika yang secara umum disepakati bersama (Herman Hudojo, 1988: 2), yaitu

1. Memiliki objek kajian yang abstrak

2. Bertumpu pada kesepakatan

3. Berpola pikir deduktif

4. Konsisten dalam sistemnya

5. Memiliki simbol yang kosong arti

6. Memerhatikan semesta pembicaraan

Secara etimologi kata Al-Quran adalah isim mashdar (kata benda) dari kata Qoro-'a dengan makna isim Maf'ul, sehingga berarti "bacaaan". Al-Quran merupakan mashdar (kata benda) dari kata kerja Qoro-'a yang bermkna Talaa keduanya berarti membaca, atau bermakna. Sedangkan pengertian AlQuran secara terminologi adalah firman Allah SWT. Al-Quran diturunkan kepada Rasulullah, Muhammad SAW. Melalui wahyu yang dibawa olrh jibril, baik lafazh maupun maknanya, membacanya merupakan ibadah, sekaligus merupakan mukjizst yang sampai kepada kita secara mutawir. Adalah kalam Alaah yang diturukan kepada Rasul dan penutupnya para Nabi-Nya, Muhammad Shallallahu'alaihi wasallam, diawali dengan surta Al- Fatihah dan diakhiri dengan surta An-Naas.

Al-Qur'an adalah firman atau wahyu yang bersal dari Allah SWT kepada Nabi Muhammad SAW dengan perantara melalui malaikat jibril sebagai pedoman serta petunjuk seluruh umat manusia semua masa, bangsa dan lokasi. Al-Quran adalah kitab Allah SWT yang terakhir setelah kitab Taurat, Zabur Dan Injil yang diturunkan kepada para rrasul melalui perantara jibril. Syaikh Abu Utsman berkata: 'Ashhabul hadits bersaksi dan berkeyakinan bahwa al-quran adalah kalamullah (ucapan Allah), Kitab-Nya dan wahyu yang diturunkan, bukan makhluk. Barangsiapa yang menyatakan dan berkeyakinan bahwa ia makhluk maka kafir" menurut pandangan mereka. Fungsi Al-Quran adalah:

1) Al-Quran sebagai petunjuk bagi manusia

2) Al-Quran sebagai sumber pokok ajaran islam 
3) Al-Quran sebagai peringatan dan pelajaran bagi manusia

4) Al-Quran sebagai mukjizat Nabi Muhammad SAW

Sebagai pedoman hidup yang benar, Al-Quran niscaya harus memberikan suatu petunjuk hidup yang benar, mendasar dan pasti. Sehingga dapat dijadikan sebagai pegangan yang kokoh dalam menghadapi hidup. Oleh karena itu tujuan utama diturunkannya Al-Quran tidak lain kecuali untuk memberikan petunjuk kepada umat manusia ke jalan yang harus ditempuh demi kebahagiaan hidup di dunia dan di akhirat. Adapun petunjuk yang diberikan oleh Allah pada pokoknya ada tiga (Chalil Munawar, 1998: 91):

1. Petunjuk aqidah dan kepercayaan yang harus dianut oleh manusia yang tersimpul dalam keimanan akan keesaan Allah dan kepercayaan akan kepastian adanya hari pembalasan.

2. Petunjuk mengenai akhlak yang murni dengan jalan menerangkan norma-norma keagamaan dan susila yang harus diikuti oleh manusia dalam kehidupannya secara individual dan kolektif.

3. Petunjuk mengenal syari'at dan hukum yang harus diikuti oleh manusia dalam hubungannya dengan Tuhan dan sesamanya

\section{Integrasi Al-Quran pada Mata Pelajaran Matematika pada Materi Pecahan}

Diawal pembelajaran guru menyampaikan degan ayat-ayat yang berkaitan dengan pecahan, seperti ayat di bawah ini:

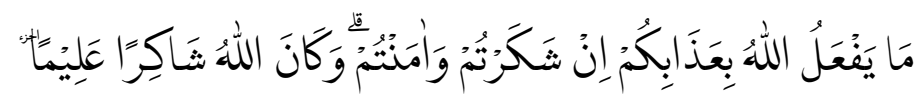

Artinya: Allah tidak akan menyiksamu, jika kamu bersyukur dan beriman. Dan Allah Maha Mensyukuri, Maha Mengetahui (QS. An Nisa' ayat 176).

Maknanya: Katakanlah: "Allah memberi fatwa kepadamu tentang kalalah (yaitu): jika seorang meninggal dunia, dan ia tidak mempunyai anak dan mempunyai saudara perempuan, Maka bagi saudaranya yang perempuan itu seperdua dari harta yang ditinggalkannya, dan saudaranya yang laki-laki mempusakai (seluruh harta saudara perempuan), jika ia tidak mempunyai 
anak; tetapi jika saudara perempuan itu dua orang, Maka bagi keduanya dua pertiga dari harta yang ditinggalkan oleh yang meninggal. dan jika mereka (ahli waris itu terdiri dari) saudara-saudara laki dan perempuan, Maka bahagian seorang saudara laki-laki sebanyak bahagian dua orang saudara perempuan. Allah menerangkan (hukum ini) kepadamu, supaya kamu tidak sesat. dan Allah Maha mengetahui segala sesuatu. Kalalah Ialah: seseorang mati yang tidak meninggalkan ayah dan anak.

Pada ayat di atas Allah menjelaskan tentang pembagian harta warisan tentang kalalah yang didalamnya terdapat jumlah seperdua dan dua pertiga, dimana seperdua dan dua pertiga itu termasuk bilangan di dalam Matematika. Hal ini menunjukkan bahwa Al-Qur'an juga berbicara mengenai Matematika, jauh sebelum para ilmuwan menemukan Matematika. Hal ini menunjukkan salah satu kemukjizatan dari Al Quran. Matematika adalah sebuah cabang ilmu pengetahuan yang wajib dipelajari dan sering kita jumpai dalam kehidupan sehari-hari. Salah satunya seperti kata seperdua, dan dua pertiga pada Surat An Nisa ayat 176 di atas dimana dalam Matematika dapat ditulis dengan angka $\frac{1}{2}$ dan $\frac{2}{3}$

\section{B. Metode}

Populasi dalam penelitian ini adalah seluruh siswa kelas VII MTsN 1 Aceh Tamiang tahun ajaran 2018/2019 yang terdiri dari 10 kelas yang berjumlah 162 siswa. Mengingat jumlah populasi yang sangat besar, maka penulis mengambil sampel secara acak. Sampel adalah bagian dari populasi yang mempunyai ciri-ciri atau keadaan tertentu yang akan diteliti (Ridwan, 2007: 11).

Pengambilan sampel dilakukan dengan menggunakan teknik Simple Random Sampling. Simple Random Sampling adalah teknik sampling yang dilakukan secara acak dengan menggunakan undian, ordinal, tabel bilangan random atau komputer (Usman, Husaini, 2006: 183). Pengambilan sampel dalam penelitian ini menggunakan teknik undian yaitu dengan membuat gulungan kertas yang berisi semua populasi dari semua kelas eksperimen. 
Ternyata setelah diundi maka didapat kelas eksperimen adalah kelas VII 1, dengan jumlah sampel seluruhnya 30 siswa. memuat sub dari sub judul, penulis dapat menggunakan heading style 3. Penulis dapat menggunakan style heading ini untuk di sub judul di bagian lain di dalam manuscript ini. Instrumen pengumpulan data dalam penelitian ini menggunakan tes yang terdiri dari lima butir soal uraian yang sudah divalidasi. analisis data menggunakan uji normalitas dan uji t satu sampel menggunakan software SPSS 17.

\section{Hasil dan Pembahasan}

Sebelum dianalisis data dilakukan pengujian prasyarat analisis terlebih dahulu

\section{a. Uji Prasyarat Analisis}

1) Uji Normalitas data Posttest

Pengolahan data dalam penelitian ini dilakukan terhadap data posttest dengan menggunakan SPSS dengan taraf signifikan $5 \%$. Berdasarkan perhitungan pada lampiran, berikut ditampilkan hasil perhitungan uji normalitas data posttest.

Tabel 1 Tests of Normality

\begin{tabular}{|l|r|r|r|r|r|r|}
\hline & \multicolumn{3}{|c|}{ Kolmogorov-Smirnov $^{a}$} & \multicolumn{3}{c|}{ Shapiro-Wilk } \\
\cline { 2 - 7 } & Statistic & $d f$ & \multicolumn{1}{c|}{ Sig. } & Statistic & \multicolumn{1}{c|}{$d f$} & \multicolumn{1}{c|}{ Sig. } \\
\hline Nilai_Posttest & .184 & 30 & .011 & .876 & 30 & .002 \\
\hline
\end{tabular}




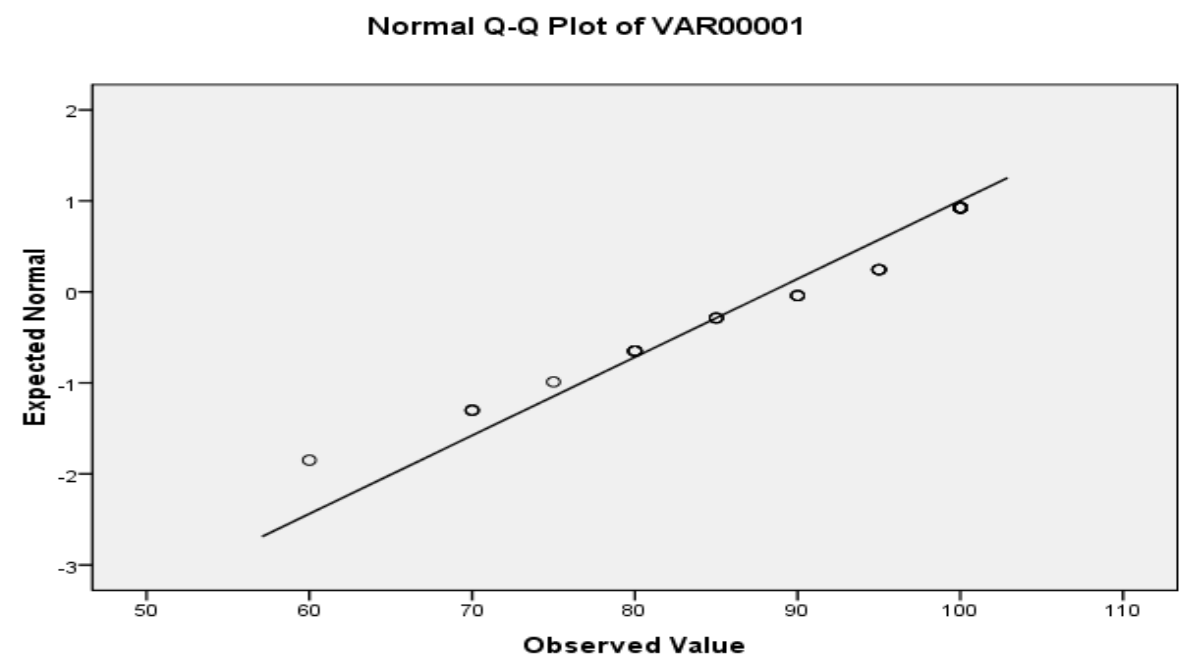

Gambar 1. Grafik Normalitas

Dari Tabel di atas dapat dilihat bahwa taraf signifikan melebihi $\alpha=$ 0,05, kemudian pada Gambar di atas terlihat grafik, data menyebar dekat dengan garis lurus, dan data mengikuti ke kanan atas sehingga dapat disimpulkan data Posttest terdistribusi normal. Pengujian hipotesis dalam penelitian ini dilakukan pada data Posttest. Setelah dilakukan pengujian normalitas terlihat bahwa data posttest adalah normal. Berdasarkan pada lampiran diperoleh data sebagai berikut:

Tabel 2. One-Sample Test

\begin{tabular}{|c|c|c|c|c|c|c|}
\hline & \multicolumn{6}{|c|}{ Test Value $=75$} \\
\hline & \multirow[b]{2}{*}{$\mathrm{T}$} & \multirow[b]{2}{*}{$\mathrm{df}$} & \multirow[b]{2}{*}{$\begin{array}{l}\text { Sig. (2- } \\
\text { tailed) }\end{array}$} & \multirow[b]{2}{*}{$\begin{array}{c}\text { Mean } \\
\text { Difference }\end{array}$} & \multicolumn{2}{|c|}{$\begin{array}{c}\text { 95\% Confidence } \\
\text { Interval of the } \\
\text { Difference }\end{array}$} \\
\hline & & & & & Lower & Upper \\
\hline $\begin{array}{l}\text { Nilai_Postte } \\
\text { st }\end{array}$ & 6.284 & 29 & .000 & 13.33333 & 8.9938 & 17.6728 \\
\hline
\end{tabular}


Berdasarkan tabel di atas diperoleh data rekapitulasi data di bawah ini:

Tabel 3. Rekapitulasi Data Hipotesis

\begin{tabular}{cccccc}
\hline \multirow{2}{*}{ Kelas } & $\bar{X}$ & $\boldsymbol{s}$ & \multicolumn{2}{c}{ Nilai t } & Kesimpulan \\
\cline { 4 - 5 } & & & $\boldsymbol{t}_{\text {hitung }}$ & $\boldsymbol{t}_{\text {tabel }}$ & \\
\cline { 1 - 1 } $\begin{array}{c}\text { Eksperime } \\
\mathrm{n}\end{array}$ & 88,33 & 11,62 & 6,284 & 1,699 & $\begin{array}{c}H_{0} \text { ditolak } \\
H_{a} \text { diterima }\end{array}$ \\
\hline
\end{tabular}

Berdasarkan Tabel di atas dapat dilihat bahwa pada taraf sigifikan $\alpha=$ 0,05 , diperoleh $t_{\text {hitung }}>t_{\text {tabel }}$ yaitu 6,284 $>1,699$, karena $t_{\text {hitung }}>t_{\text {tabel }}$ hal ini berati bahwa $\mathrm{H}_{0}$ ditolak dan $\mathrm{H}_{a}$ diterima, yaitu penerapan pembelajaran matematika yang direlavansikan dengan nilai-nilai Al-Quran dikatakan baik jika nilai rata-rata $\geq 75$. Berdasarkan hasil analisis data penelitian, diperoleh bahwa rata-rata posttest 88,33 dan hasil uji hipotesis dengan menggunakan uji-t diperoleh nilai $t_{\text {hitung }} \geq t_{\text {tabel }}$ yaitu $6,284 \geq 1,699$, pada taraf signifikasnsi 5\%. Dari hal tersebur dapat disimpulkan bahwa penerapan pembelajaran matematika yang direlevansikan dengan nilai-nilai Al-Quran dalam membentuk pendidikan moral dikatakan baik karena tercapai nilai rata-rata di atas 75 .

\section{Kesimpulan}

Adapun kesimpulan dari penelitian ini adalah Penerapan pembelajaran matematika pada materi pecahan dengan menggunakan nilai-nilai al-quran di MTsN Aceh Tamiang dapat dikatakan baik karena tercapai nilai rata-rata di atas 75. Hal ini berdasarkan hasil analisis data penelitian, diperoleh bahwa rata-rata posttest 88,33 dan hasil uji hipotesis dengan menggunakan uji-t diperoleh nilai $t_{\text {hitung }} \geq t_{\text {tabel }}$ yaitu $6,284 \geq 1,699$, pada taraf signifikasnsi $5 \%$. 


\section{E. Saran}

Adapun saran dari penelitian ini adalah Bagi guru mata pelajaran matematika seharusnya ketika mengajar mengaitkan materi matematika dengan al-quran karena dari hasil penelitian ini diperoleh hasil yang sangat baik dari segi nilai siswa.

\section{UCAPAN TERIMA KASIH}

Penulis mengucapkan terima kasih kepada seluruh guru di MTsN 1 Aceh Tamiang dan juga siswa di MTsN 1 Aceh Tamiang serta seluruh dosen PMA atas dukungannya baik secara material maupun secara moril.

\section{DAFTAR PUSTAKA}

Abdusysyakir. 2006. Ada Matematika dalam Al_Quran, UIN Malang Press, Malang.

Ali Abdul Halim Mahmud. 2004. Akhlak Mulia, Penerjemah Abdul Hayyie Alkattami, Gema Insani Press, Jakarta.

2003. Tarbiyah Khuluqiyah: Pembinaan Diri Menurut Konsep Nabi, Media Insani, Solo.

, 2004. Akhlak Mulia, Penerjemah Abdul Hayyie Alkattani. Gema Insani. Jakarta.

Arikunto, Suharsimi. 2007. Manajemen Penelitian, Rineka Cipta, Jakarta. 2009. Dasar-dasar Evaluasi Pendidikan, Bumi Aksara, Jakarta.

Erman Suherman dkk. 2003. Strategi Pembelajaran Matematika Kontemporer, Jica, Edisi Revisi.

Herry Mohammad. 2006. Tokoh-tokoh Islam Yang Berpengaruh Abad 20. Gema Insani. Jakarta.

Riduwan. 2007. Belajar Mudah Penelitian untuk Guru-Karyawan dan Peneliti Pemula. Alfabeta, Bandung.

Tim Penyusun Kamus Pusat Pembinaan dan Pengembangan Bahasa Departmen Pendidikan dan Kebudayaan. 1994. Kamus Besar Bahasa Indonesia, Balai Pustaka Jakarta. 
Usman, Husaini \& Purnomo Setyady. 2006. Pengantar Statistika. Bumi Aksara, Jakarta. 
